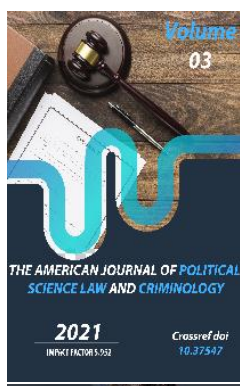

\title{
Political Forecasting As An Integral Part Of Optimizing Public Strategic Management
}

Fatkhulla Habibullaevich Hikmatov

Doctor Of Philosophy (PhD) On Political Sciences, Tashkent State Technical University, Uzbekistan

Journal Website: http://usajournalshub.c om/index,php/tajpslc

Copyright: Original content from this work may be used under the terms of the creative commons attributes 4.0 licence.

\section{ABSTRACT}

The main content of the article is currently concerned only with the problems of methodology and methodology of political forecasting: the ability to see political change adequately is one of the main conditions for the correct view of political management strategies and tactics, targeted influence on political processes. The article analyzes such issues as the strength and continuity of the "forecasting - planning - management" chain, as the most important factor in achieving current and long-term goals and objectives for the political subsystem, institutions, entities and society as a whole. It also analyzes the experience of developed countries in determining the status of forecasting efficiency analysis centers through their relations with various government agencies.

\section{KEYWORDS}

Political forecasting, reliability, level of forecasts, political system, strategy, strategic thinking, tactics, futurology, military strategy, real space, information space, virtual space, political decision, forecasting, think tank, future studies, future research, collective decision making,

Forecasting is a very complex science, especially

if they relate to the future

(Nils Bor) 


\section{INTRODUCTION}

Public policy is extremely important role in public life. It is she who has the goal of timely identifying urgent problems of the development of society, analyzing them, establishing the causes of their occurrence, complexity, inconsistency and finding solutions. In the field of state policy, appropriate state-political decisions are made to solve a specific problem, and appropriate programs and instruments are developed. The process of developing and implementing public policy is multifaceted and diversified. One of the most important links in this process is political forecasting. A successful political forecast provides a realistic vision of reality and, accordingly, forms the basis for making a decision with an understanding of what is happening or should be realized. The lack of scientific and analytical support for state policy determines the slow pace and difficulties of the development of society. The consequence of this, in particular, is that the problems of society are recognized and become the subject of theoretical research and practical solutions after they have become aggravated.

\section{RESEARCH METHODOLOGY}

In the modern world, the problems of methodology and methodology of political forecasting are of interest not only among experts in this field, but the ability to see political change adequately is analyzed as one of the main conditions for the correct construction of political governance strategies and tactics. The strength and continuity of the "forecasting - planning - management" chain is

\footnotetext{
1 Кризисы и прогнозы в свете теории длинных волн Москва.: изд-ва «Учитель», 2016. Под ред. Л. Е. Гринина, А. В. Коротаева, Р. С. Гринберга. С34.
}

the most important factor in the implementation of current and long-term goals and objectives for a particular political subsystem, institution, entity, society as a whole.

When embarking on research in the field of methodology and methodology of political forecasting, it is first necessary to identify and formulate the main parameters of the requirements for political forecasting today, its characteristic aspects as a separate type of probabilistic political knowledge. In addition, the adoption of political decisions of strategic importance in modern Uzbekistan requires a clear picture of the specific conditions in which the political system operates, the course of political processes.

There are a number of terms related to knowing the future in the scientific literature: foresight, prediction, prediction, forecasting, futurology, and so on. However, since the goals and objectives of our research do not include a comprehensive analysis of this issue, i.e., the essence of the terms, we will focus only on issues within the scope of research. The difference between prediction and forecasting is that prediction is a pre-reflection of reality based on an understanding of the laws of nature, society, and thought, and prediction is a scientifically based idea of what may happen to an object in the future or alternative ways and deadlines ${ }^{1}$.

Political forecasting as a field of theoretical and practical knowledge studies the dynamic change of the political system, its structure and elements over time. In other words, its subject is political processes ${ }^{2}$. According to G. Glezerman, foresight is focused on qualitative changes in society in the future, and

2 Политическое управление. -Москва.: РАГС, 2009. C-37. 
forecasting - on quantitative changes ${ }^{3}$. According to the American researcher $\mathrm{L}$. Bloomfield, if a prediction indicates events that may occur (prediction); anticipation - classes of events (anticipation); forecasting shows the classes of events that may occur in the future (forecasting) ${ }^{4}$.

Thus, general research shows that the concept of "forecast" must meet a number of requirements: 1) it must be probabilistic; 2) scientifically based; 3 ) indicate the future state of the object or alternative ways, deadlines, resources to achieve its specific state; 4) an indication of the forthcoming specific situation.

We consider it expedient to consider some of the views of the famous futurist $G$. Kan as a master of strategic thinking. G. Kahn is known for his works on American military strategy and nuclear strategy. G. Kan Guddonovsky founded the institute as the main type of "think tank" and within the framework of his proposed methodology divided it into 6 types according to the level of prediction of events:

- Resilience (climate, language, faith, etc.);

- Gradually changing (natural resources, demography, GDP, tax policy, etc.).

- Predictor - (specific scenarios, key forces, unsolvable problems, etc.).

- Coincidences (consequences of revolutions or wars, several types of external pressure, spontaneous poverty).

- Unaccounted for (including the causes or excessive complexity of unknown and unanalyzed mechanisms) 5 .

\footnotetext{
3 Ахременко А. С. Политический анализ и прогнозирование. Введение в количественные методы.М.: Изд, Московского университета, 2012.C-15.

${ }^{4}$ Bloomfield L. P. Short-order futures: short-range forecasting in foreign affairs / Forecasting in international relations: Theory, Methods, Problems, Prospects. San Francisco, 1978. P- 278-289.

5 Kahn H. "History happens in «Kmight lines and curves" // American Outlook. - 1999. - Winter
}

At present, there is no single opinion on the relationship between forecasting and futurology. Often, these concepts are used as synonyms. Interestingly, in a 1970 survey of members of the Association for the Study of the Future to find the most suitable names for the field of future research, futurology came in only sixth out of 22 names, with the first two on the list "future studies" and "future research". The effectiveness of political forecasting is determined, firstly, by the degree of reliability of forecasts, secondly, more precisely, and thirdly, by whether one or another forecast helps to increase the validity, objectivity and effectiveness of political decisions made on the basis of such forecasting.

There are two main views among American researchers on the level of reliability and accuracy of forecasts, including foreign policy forecasts. The first of these views is that it is practically impossible to predict foreign policy processes as a result of their complexity, but only to make some logical or intuitive assumptions about the future. The second view recognizes that the future can be predicted by indicating the probability that each of the alternatives will materialize ${ }^{7}$.

Representatives of the first point of view, K. Norr, O. Morgenshtern, question the correctness of the concepts of "foresight" and "forecasting" in the study of international relations and use a more acceptable concept, such as "hypothesis". They point to the most recent history to confirm their point of view, noting that two world wars, the Vietnam tragedy, the Israeli war with the Arabs (1967),

6 Paul Dickson. Think Tanks. - New York, Atheneum, 1971. Перевод на русский язык с сокращениями. - М., «Прогресс», 1976. // Электронная публикация: Центр гуманитарных технологий. _ $\quad$ 01.08.2006. URL: https://gtmarket.ru/laboratory/expertize/3026/3037

${ }^{7}$ Кислицын С.В. Долгосрочное прогнозирование в США: институциональный аспект. Анализ и прогноз. Журнал ИМЭМО РАН, 2019, № 2, С-23. 
and similar events were not predicted $^{8}$. According to $\mathrm{O}$. Helmer, the second view related to the name of $M$. Kaplans is that as the methods of forecasting develop, there may be positive changes compared to the past ${ }^{9}$.

According to Bell, "because there are no algorithms in politics, it is possible to evaluate events in one country, just as the CIA does, but it is not possible to accurately assess events around the world and predict what they will look like in the future ${ }^{10}$.

According to S. Sargsyan and L. Galvanov, the level of reliability and accuracy of forecasts is affected by the following factors: 1) a significant reduction in prognostic estimates due to extreme caution; 2) excessive prognostic estimates; 3 ) unpredictability of the future due to narrow vision and lack of information about the projected object; 4) not to be critical of authoritative opinions; 5) unclear definition of relationships and interactions; 6 ) inability to predict the future of the system at a higher level than the projected object ${ }^{11}$.

Thus, the accuracy and reliability of forecasting are theories based on analysis; completeness and reliability of primary data; how the forecast is conducted; who will make the forecast will also depend on random factors.

The geopolitical concept that Collins expressed in 1980 that the sources of national integration and disintegration would be mainly in the field

\footnotetext{
${ }^{8}$ Klaus Knorr and Oskar Morgenstern, Science and Defense: Some Thoughts on Military Research and Development, Center of International Studies, Princeton University, Policy Memorandurn No. 32, February 18, 1965.

${ }^{9}$ Helmer $O$. Political Analysis of the Future. P.; L., 1969. P-31. Kaplan M. System and Process in International Politics. New York., 1957.P-63.

10 Белл Д. Грядущее постиндустриальное общество. Опыт социального прогнозирования / Перевод с англ. под ред. В.Л.Иноземцева. Москва., Academia, 1999 // Свободная мысль-XXI. 2000. № 12. C-65.
}

of material factors such as military power and geographical location (e.g., the period of instability in the USSR and the long-term disintegration of the "Russian Empire", as well as the loss of the USSR's control over Eastern Europe and its own collapse. had predicted that it would bring ${ }^{12}$. As a result, although he made a mistake in time, R. Collins clearly predicted a period of instability in the USSR ${ }^{13}$.

According to U.S. researcher F. Schrodt, the biggest failures in predicting U.S. foreign policy in the 2oth century include Pearl Harbor, predictions of the government's achievements in Vietnam until 1968, and defeats in predicting the end of the Cold War. It failed to predict the end of the Cold War and the impending collapse of the Soviet system, despite the efforts of thousands of analysts who used information worth tens of billions of dollars a year, the observations of journalists and others, and the ideological assumptions that communism was in fact flawed and ineffective. According to Schrodt, such a failure in forecasting US foreign policy was due, on the one hand, to the inability of analysts who had devoted their lives to the study of the Communist Party of the Soviet Union to imagine their lives without it, and, on the other, to the "Soviet threat." was dependent. As a result, this defeat, according to F. Schrodt, cost the United States an additional \$ 500 billion,

\footnotetext{
11 Саркисян С.А., Голованов Л.В. Прогнозирование развития больших систем. Серия Математическая статистика для экономистов М. Статистика 1975г. С-92.

${ }^{12}$ Randall Collins What Does Conflict Theory Predict about America's Future? 1993 Presidential Address Sociological Perspectives, Vol. 36, No. 4. published by University of California Press. (Winter, 1993), P296.

${ }^{13}$ Randall Collins What Does Conflict Theory Predict about America's Future? 1993 Presidential Address Sociological Perspectives, Vol. 36, No. 4. published by University of California Press. (Winter, 1993), P297
} 
and Eastern Europe remained under communist control for another 5-7 years ${ }^{14}$.

Another situation should not be overlooked. That is, another common element of the last period is the problem of international processes of collective decision-making. As an example, when the United States launched the war against Iraq, it withdrew from the collective decision-making process, which angered many international actors. Decisionmaking at the domestic political level is also quite problematic, as it collides with internal and external military priorities. In Iraq and Vietnam, for example, intelligence experts have spoken out against the war. However, many experiments show that important decisions are made under political pressure and the opinion of experts is not taken into account. For example, when the U.S. military invaded a part of Cuba, the population thought it did not protect the Castro regime, but went astray $^{15}$. The complexity of the decision-making process, both externally and internally, is related to the complexity of analyzes in the field of internal security.

The former U.S. President George W. Bush also explores the challenges faced by the administration in decision-making: policy must be presented to an internal and external audience, often the problem of presenting it correctly arises because both audiences must be satisfied; there is a gap between theory and

\footnotetext{
14 Schrodt P. A. Forecasts and Contingencies: From Methodology to Policy. "Political Utility and Fundamental Research: The Problem of Pasteur's Quadrant" at the American Political Science Association meetings, Boston, 29 August -1 September 2002. P-17

${ }^{15}$ Schrodt P. A. Forecasts and Contingencies: From

Methodology to Policy. "Political Utility and

Fundamental Research: The Problem of Pasteur's

Quadrant" at the American Political Science

Association meetings, Boston, 29 August -1

September 2002. P-18

${ }^{16}$ Moore J. a.o. Bush's brain. How Karl Rove made George W. Bush presidential. Hoboken, New Jersey, 2003. P- 46.
}

practice in the implementation of domestic and foreign policy; there is a difference between goals and means in domestic and foreign policy ${ }^{16}$. For example, even though the defense budget has a multi-billion-dollar potential, it failed to stop 19 terrorists, and this showed that the detention policy was wrong ${ }^{17}$. The international policy pursued by the United States today without the consent of international institutions is causing a great deal of discontent. Thus, the accuracy of the forecasts will depend on who makes the forecast, i.e., the forecaster. According to their functions, experts distinguish four main types of US foreign policy forecasting: 1) forecasting of foreign policy aimed at creating a single political-philosophical vision of the future in certain groups of people (works of D. Bell, Z. Brzezinski and others) ${ }^{18}$;

2) forecasting aimed at mobilizing certain groups of people or society as a whole for this or that action (E. Toffler's works, lectures to the Club of Rome, etc.) $)^{19}$; 3) forecasting aimed at developing theories of international relations, developing hypotheses, concepts and testing (for example, in 1966-1967 by Princeton University researchers $\mathrm{Ch}$. Hermann and N. Hermann using the method of simulation games. Retrospective analysis of the probability of the First World War and

\footnotetext{
${ }^{17}$ Moore J. a.o. Bush's brain. How Karl Rove made George W. Bush presidential. Hoboken, New Jersey, 2003. P- 46.

Moore J. a.o. Bush's brain. How Karl Rove made George W. Bush presidential. Hoboken, New Jersey, 2003. P- 47.

18 Белл Д. Грядущее постиндустриальное общество. Опыт социального прогнозирования / Перевод с англ. под ред. В.Л. Иноземцева. Москва, Academia, 1999 // Свободная мысль-ХХІ. 2000. № 12. С. 60-70; Бжезинский 3б. Стратегический взгляд. Америка и кризис глобальной власти. Москва.: АСТ, 2013. С-85.

19 Тоффлер Э. Шок будущего: Пер. с англ. Москва.: «Издательство АСТ», 2002. С-157.
} 
others $)^{20}$; 4) forecasting aimed at optimizing the adoption of foreign policy decisions ${ }^{21}$.

As the forecast period increases, its level of accuracy decreases significantly, as with the extension of the forecast period, the number of factors that have not been observed in the past and are not taken into account in the analysis of the initial database of forecast data increases. In long-term forecasting, the number of variables that can affect the prognosis increases as we move away from the present. Therefore, other methods are less commonly used in long-term forecasting than some methods.

The effectiveness of forecasting is determined by the status of the analysis center, its relations with various government agencies. Often, decisions of the highest bodies of state power are made on the basis of research conducted by think tanks, because such centers take into account a broader aspect, they know the details of issues discussed in interdepartmental agreements and interstate negotiations, they use operational information. As a result, it is incorrect to assume that the "independent" or "public" analysis is much better than the preagency, institutionally linked analysis, as the level of reliability and accuracy is determined by the adequacy of the information. Schrodt disagrees that the data used by "academic" researchers is not sufficient for forecasting ${ }^{22}$. $F$. Schrodt cites confidential analysis data as an example ${ }^{23}$. Such reports spoke of the USSR as a strong rival, contrary to the information used by journalists and tourists about the imminent

\footnotetext{
${ }^{20}$ Political Game Theory: An Introduction (Analytical Methods for Social Research) 1st Edition by Nolan Mc Carty, Adam Meirowitz . Cambridge University Press; 1 edition (January 8, 2007) P-102.

${ }^{21}$ Political Game Theory: An Introduction (Analytical Methods for Social Research) 1st Edition by Nolan Mc Carty, Adam Meirowitz . Cambridge University Press; 1 edition (January 8, 2007) P-102.

${ }^{22}$ Schrodt P. A. Forecasts and Contingencies: From Methodology to Policy. "Political Utility and Fundamental Research: The Problem of Pasteur's Quadrant" at the American Political
}

collapse of the Soviet system during Gorbachev's rule. However, in our opinion, such an assertion of F. Schrodt is not about the sufficiency of the initial information, but rather about the issue of their reliability and completeness.

Furthermore, American researcher Ch. Cooper points out that in the second half of 1972, independent analysis centers were tasked incorrectly as a reason for lack of forecasts for political decision-making, as independent analysis centers were tasked by less informed individuals due to their lower office or distance from the center. More informed people, on the other hand, are unable to work with surface researchers due to over-employment ${ }^{24}$. In particular, the effectiveness of foreign policy forecasting by think tanks and analysts: constructive interaction with the foreign policy apparatus and the political community (direct contacts with government agencies, liaison with the legislature, participation in various diplomatic receptions by think tanks and analysts) etc.); formation of foreign policy discourse (public speeches of representatives of analytical centers and analysts at meetings of major universities, academic forums, professional associations, articles of analytical centers and analysts); public appearances in the media will also increase due to relevance and timeliness.

According to Cooper, effectiveness is determined not only by how well researchers make predictions, but also by how seriously

Science Association meetings, Boston, 29 August -1 September 2002. P-23.

${ }^{23}$ Schrodt P. A. Forecasts and Contingencies: From Methodology to Policy. "Political Utility and Fundamental Research: The Problem of Pasteur's Quadrant" at the American Political Science Association meetings, Boston, 29 August -1 September 2002. P-23.

${ }^{24}$ Cooper, Charles (ed.) (1973) Science Technology and Development: The Political Economy of Technical Advance in Underdeveloped Countries. London: Frank Cass. P-107. 
key officials in the political hierarchy take such predictions ${ }^{25}$.

Politicians take into account the results of prognostic research when making decisions, but do not always follow them. In particular, on the eve of the US withdrawal of troops from Cambodia in April-May 1970, G. Kissinger played an imitation or practical game with five members of his staff, who were supposed to oppose the entry of troops ${ }^{26}$. The task of this game was to determine the factors that would oppose this or that movement in the United States. As a result, evidence was presented during the game against the incursion of U.S. troops into Cambodia (including the possibility that such a move could lead to an escalation of the war in Indochina and negative relations within the country and around the world). But despite the fact that the outcome of the game was presented to US President R. Nixon, the president personally decided to bring in troops. As a result, "the operation was successful from a military point of view, but in fact it was not necessary, and politically wrong"27.

In addition, one of the key issues in forecasting effectiveness is that significant changes, often in the form of reforms, are planned at the higher levels of government, and their implementation takes place at the level of primary levels. As a result, the implementation of the decisions made will depend not only on the real and probable views of the ruling elite, but also on the mass processes taking place at the grassroots level.

Strategy differs from tactics in that it works within a multifaceted space. As a result, an inter-level effect is formed, in which it is understood that actions in one space can yield

\footnotetext{
${ }^{25}$ Development studies revisited. Twenty-five Years of The Journal of Development Studies.With an Introduction by Charles Cooper and E.V.K. FitzGerald. Third Avenue, New York. 2016. P 125

${ }^{26}$ Генри Киссинджер. Дипломатия.1994. Пер: В. Н. Верченко. Издательство АСТ. 2017. С-340.
}

results in another. The opponent / rival may not even feel the danger because he can see everything within one space.

Strategy looks to the future, and tactics look to the present. Today has certain limits, beyond which the situation will change radically, that is, the transition to the future will take place. From today, the future can only be seen through this boundary. That is, strategy exists in virtual space and tactics in real space.

It should not be overlooked that it is the virtual space that shapes the real space to the desired level. That is why the struggle for the virtual space of countries is underway. Old heroes, ideologies, values are denied, they are weakly described, the virtual space of an entire country is occupied and reshaped. For example, Lenin used to be a hero on stage and in cinema, but today he cannot be a hero.

At the same time in the space is not only planning the situation, but also a clear struggle. Working in a virtual space allows:

- Setting goals for the enemy;

- Change their goals for him;

- To create a false image in him to change the purpose of the enemy;

- Change the decision-making process ${ }^{28}$.

As a result, in addition to waging war without declaring it to the opponent, it is also possible to end it without announcing that the opponent has been defeated.

Today, the structure of motion is created in 3 interconnected spaces: real space, information space, and virtual space. As we saw above, the goal is to occupy virtual space, because

\footnotetext{
${ }^{27}$ Генри Киссинджер. Дипломатия. 1994. Пер: В. Н. Верченко. Издательство АСТ. 2017. С- 345.

28 Analysis, Analysis Practices, and Implications for Modeling and Simulation. Paul K. Davis, Amy Henninger. RAND National Defense Research Institute. Published 2007 by the RAND Corporation 2007. P- 78
} 
through it is possible to interact with other spaces.

The information space is located between the real and virtual space and can play the role of changing two spaces. While information space is characterized by dynamic changes, physical and virtual space change slowly.

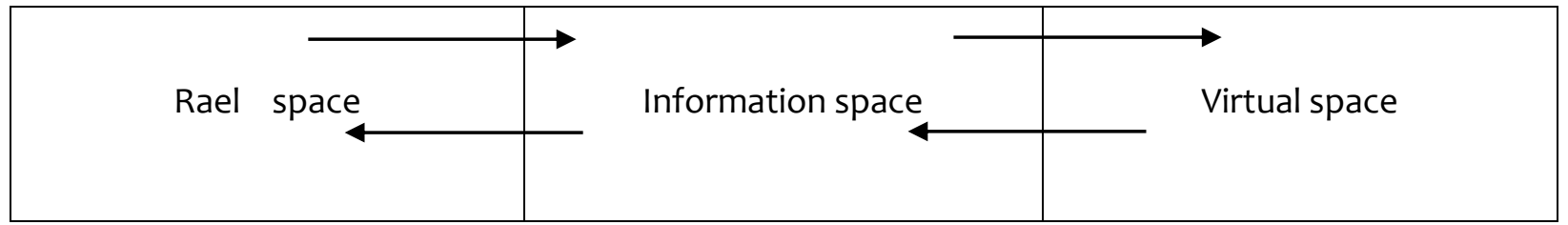

For example, K. Rove believes that at the heart of everything lies the control of the country's information agenda ${ }^{29}$. This is understandable because information space can define the internal environment of both real and virtual space. Here is the answer from a person who was one of Carl Rove's employees. Carl Rove asked his staffer, "Do the American people compare the war on terrorism to World War II?" The employee replies after a while: "No, they don't think so, they want us to think this war is like World War II." Taking World War II as an example, the focus is on information and ideological support ${ }^{30}$. If the information space is in conflict with the virtual space, the virtual space loses the information space.

The following directions for the formation of the future can be identified: the formation of a virtual space under the control of real space; shaping real space under virtual space control. For example, the revolution of 1917 in Russia, the policy of reconstruction in 1985-1991 reshaped reality, changed the physical space. Changes in virtual space have changed real space.

\footnotetext{
${ }^{29}$ Moore J. Bush's brain. How Karl Rove made George W. Bush presidential. - Hoboken, New Jersey., 2003 P-273.

${ }^{30}$ Moore J. Bush's brain. How Karl Rove made George W. Bush presidential. - Hoboken, New Jersey., 2003 P-274.

${ }^{31}$ Hoffman D.E. Reagan approved plan to sabotage Soviets. Book recounts ('old War program that made
}

Another example is that at the end of the twentieth century, CNN news was shaping public opinion, and under its pressure, Americans were forced to withdraw their troops from Somalia ${ }^{31}$. So, before the war in Afghanistan, Powell advised the military to stay away from CNN. Before the war in Afghanistan, J. Bush Jr. formed his own communicative team, which included K. Rice, K. Hughes, D. Barlet, A. Fleischer. The purpose of the communicative command was to form an appropriate understanding in the American people, to explain the purposes of the White House $^{32}$. The success of this persuasion campaign would determine the success of the White House. "I'm a Vietnamese product," Bush said. "I remember unsupported war presidents at a time when the nation was divided." The reason was that America was defeated in the virtual space, so it was forced to retreat in the real space ${ }^{33}$. Henson advises considering the military, diplomatic, philosophical, and cultural aspects of war ${ }^{34}$. Because war is fought on all fronts.

The fight against uncertainty is based on the virtual component as the main task of the

technology go haywire // Washington Post. -2004. February 27

${ }^{32}$ Woodward B. Bush at war. - New York etc., 2002. P. 95

${ }^{33}$ Woodward B. Bush at war. - New York etc., 2002. - P-87.

${ }^{34}$ Hanson V.D. Ripples of battle. How wars of the past still determine how we fight, how we live and how we I think. - New York etc., 2003. - P-199. 
strategy. Speaking about Rumsfeld, Deputy Secretary of Defense D. Fayette said: "His big strategic issue is uncertainty. The need for strategic work with uncertainty. The inability to predict the future is the "limit of our knowledge and intellect". He notes that he dislikes Rumsfeld's prediction: "virtual filling; structuring; reliability assessment. We fill in the uncertainties with our imaginations, then structure them, and then determine their level of reliability ${ }^{35}$.

Another variant of virtual strategic thinking was proposed by T. Sauvel, who called it "playing beyond the first step"36. However, many social problems are solved through compromises that can occur at a later stage.

An example of this is the findings of the American scientist Justin McCurry. He estimates that by 2020 , the number of unmarried men in China will reach 40 million. In China, there was one child policy per family, with families mostly wanting to have a son. As a result, boys began to make up a much larger number than girls. To prevent this problem, posters saying "Girls are as good as boys" were hung in some villages ${ }^{37}$. That is, virtual space is in conflict with real space, creating a state of crisis. The issue of virtuality is relevant for postSoviet countries as they have lost their heroes. Without a hero, there will be no influence of national ideology.

Therefore, the following specific actions should be taken: "check" the heroes in the interior; a "check" of external heroes present in the virtual space; analysis of ways to create new heroes. If we create our own hero, we can form our own virtual space variant with our own desires and objections. The "virtual

\footnotetext{
${ }^{35}$ Fallow J. Blind into Baghdad // Allanlic. - 2004. January/February

36 Goode S. Sowell reaches beyond rhetorics // www.insightinag.com

37 Justin McCurry. a.o. $40 \mathrm{~m}$ bachelors and no woman... the birth of new problem for China // Guardian. - 2004. - March 9
}

platform" defends what it knows to be true in terms of reality.

This can also be seen in the arguments given by D. Fram and R. Pearl, who try to justify the formation in this direction for the following reasons: "society describes women as slaves, teaches men to be strict towards women; ignorance breeds fanaticism, ignorance prevails everywhere in a society that keeps women ignorant; in different cultures, unemployed men cannot marry, and the inability of men to have sex causes young men to become angry; in a society where women have political rights, they oppose social discord and ideological radicalism " 38 . In Pakistan, 33\% of women do not know how to read, so the United States supports a UN program that provides child education in the country. For example, in practice, the "fat for reading" program, according to which every girl who studies at school for 20 days receives 4 liters of fat $^{39}$. We can see that the transformation of mass consciousness is accomplished through the transformation of women's consciousness. Men's consciousness cannot be changed because it has been formed.

P. Wolfowitz points out that half of the population of Arab countries is women and this is one of the ways to transform the mass consciousness. The adoption of laws banning Muslims from wearing headscarves in French schools is also one of these areas. Loss of external signs of a foreign system is also very important, because in this way it is possible to enter or swallow a foreign system. A Muslim woman without a headscarf is easily accepted by French society, or the French welcome modern Arab women well ${ }^{40}$.

\footnotetext{
${ }^{38}$ Frum D., Perle R. An end to evil. How to win the war on terror. - New York, 2003. - P-150.

${ }^{39}$ Deputy secretary Wolfowitz interview with the New Yorker Festival // www.defenselink.mil

${ }^{40}$ Deputy secretary Wolfowitz interview with the New Yorker Festival // www.defenselink.mil
} 
What should the strategy do to shape the future? To answer the question, we can cite the following set of situations: merging two separate objects; transition to the future from a real object that has not yet taken place in practice; creating a context that facilitates the appearance of the object; creating a context that does not facilitate the appearance of the object; create a set of objects of the same type; Forming an object with unique properties.

\section{CONCLUSION/RECOMMENDATIONS}

The analysis of the issues raised in this part of the study allows us to draw the following conclusions. Forecasting is a very important function of managing political events, has a significant impact on the main directions of political development, reflects the whole set of complex external and internal connections and connections between different spheres of political life. The principles of political forecasting stem from the nature of political activity and the characteristics of forecasting activities in the structure of strategic development and management of political activity.

Political practice shows that the degree of validity of a decision made at any level of strategic management is determined by the number of alternatives considered and the depth of forecasting. The promotion of the principle of alternative as one of the most important principles of political forecasting is related to this situation.

Today, in practice, all events, processes, events are evaluated in terms of alternatives. The formation of alternatives must take into account the impact of specific policy objectives.

It should be noted that today, on the one hand, the problems of political forecasting in the applied political science of our country are poorly studied at the scientific and methodological level. On the other hand, there is little demand for professional political forecasting methods in the activities of organizations that serve to make political decisions and implement them: analytical departments of public administration, political parties, political consultation centers. Scientifically based forecasting and analytical activities are often regarded by leaders at various levels as an excessive "luxury" that is still not worth the involvement of material, human and information resources. At the same time, the consequences of various political crises that have shaken the world community and Uzbekistan in recent years, without exaggeration, the adoption of technology of political forecasting - a matter of life and death for the state, civil society, political organizations and private entrepreneurship.

Based on the above analysis, it can be noted that, first, it is impossible to effectively manage the political activity of the state without forecasting the main trends in the development of political forecasting. Second, forecasting is a very important and integral part of strategic planning and management. Third, political forecasting based on the considered principles and approaches is a subject-practical activity aimed at providing scientifically developed, systematic and reliable forecasts of political development. Fourth, due to its functional orientation and unity of theoretical basis, the "forecasting planning - management" link is a single system, the interconnectedness and complementarity of its elements is a very important factor in the effective implementation of strategic goals and objectives in political activity.

The selection of strategies, decision-making, and their implementation will not be effective enough without constant and reliable forecasting.

\section{REFERENCES}

1. Кризисы и прогнозы в свете теории длинных волн Москва.: изд-ва «Учитель», 2016. Под ред. Л. Е. Гринина, А. В. Коротаева, Р. С. Гринберга. С-34. 
Doi: https://doi.org/10.37547/tajpslc/Volume03Issue04-16

19. Генри Киссинджер.

Дипломатия.1994. Пер: В. Н. Верченко. Издательство АСТ. 2017.

C- 345 .

20. Analysis, Analysis Practices, and Implications for Modeling and Simulation. Paul K. Davis, Amy Henninger. RAND National Defense Research Institute. Published 2007 by the RAND Corporation 2007. P- 78

21. Hoffman D.E. Reagan approved plan to sabotage Soviets. Book recounts ('old War program that made technology go haywire // Washington Post. -2004. - February 27

22. Woodward B. Bush at war. - New York etc., 2002. - P-87.

23. Hanson V.D. Ripples of battle. How wars of the past still determine how we fight, how we live and how we I think. - New York etc., 2003. - P-199.

24. Fallow J. Blind into Baghdad // Allanlic. - 2004. - January/February

25. Goode S. Sowell reaches beyond rhetorics // www.insightinag.com

26. Justin McCurry. a.o. $40 \mathrm{~m}$ bachelors and no woman... the birth of new problem for China // Guardian. - 2004. - March 9

27. Frum D., Perle R. An end to evil. How to win the war on terror. - New York, 2003. - P-150.

28. Deputy secretary Wolfowitz interview with the New Yorker Festival // www.defenselink.mil 